Jianxin Liu*

Faculty of Arts and Education

Charles Sturt University, Australia

rliu@csu.edu.au

Jebunnesa Jeba

Faculty of Arts and Education

Charles Sturt University, Australia

jejeba@csu.edu.au

\title{
CHANGING COMMUNICATIVE PURPOSES OF ACADEMIC JOURNAL WRITING IN TRANSITION TO MULTIMODALITY
}

\section{Abstract}

The past decade has seen growing influence of multimodality over writing for academic journals, as well as an overall lack of research attention. In our analysis reported in this paper, we position academic journals as a text space where genres such as research articles are accommodated. We focus our analysis on examining communicative purposes of academic journal writing, a defining feature of genre often used for speedy identification of change in the field. Drawing from the related work on framing (Andrews, 2013) and context (Van Dijk, 2008), we developed an analytic framework that can help capture and delineate communicative purposes, and then used it to conduct a single case analysis of a longstanding open-access academic journal, Kairos. Our analysis suggests that communicative purposes of academic journal publishing are rapidly diversifying alongside multimodality inclusion to facilitate scholarship transaction, not only among the academia but also with the public. We suggest that further studies be undertaken to invigorate this area of research by incorporating larger database or other methods, to provide more nuanced theoretical and pedagogical scrutiny.

\section{Key words}

academic English writing, genre, communicative purposes, framing, context, multimodality.

* Corresponding address: Jianxin Liu, School of Teacher Education, Charles Sturt University, Panorama Ave, Bathurst, NSW Australia 2795. 


\section{Sažetak}

Poslednje decenije svedoci smo sve većeg uticaja multimodalnosti na pisanje u akademskim časopisima, kao i opšteg pomanjkanja istraživačke pažnje. U analizi u ovom radu, akademske časopise smatramo tekstualnim prostorom u kojem su smešteni žanrovi poput naučnih članaka. Pažnju usmeravamo na istraživanje komunikativnih namera pisanja u akademskim časopisima, definišuće svojstvo žanra koje se često koristi za brzu identifikaciju promene u toj oblasti. Oslanjajući se na slične radove o uokviravanju (Andrews, 2013) i kontekstu (Van Dijk, 2008), osmislili smo analitički okvir pomoću kojeg je moguće uočiti i razgraničiti komunikativne namere, a zatim smo unutar tog okvira sproveli analizu Kairosa, akademskog časopisa u otvorenom pristupu sa dugom tradicijom izlaženja. Naša analiza sugeriše da se komunikativne namere akademske periodike brzo diversifikuju uz prisustvo multimodalnosti kako bi se olakšala naučna komunikacija, ne samo unutar akademske zajednice, već i sa zainteresovanom javnošću. U cilju razvoja ove oblasti istraživanja predlažemo dalje studije na većem korpusu podataka ili uz pomoć drugih metoda, kako bi se omogućili precizniji teorijski i pedagoški uvidi.

\section{Ključne reči}

akademsko pisanje na engleskom jeziku, žanr, komunikativne namere, uokviravanje, kontekst, multimodalnost.

\section{INTRODUCTION}

In this article, we analyze the impact of multimodality on academic journal writing in digital times, focusing on its communicative purposes (henceforth CPs). As a defining feature of genre, $\mathrm{CP}$ can help reveal what kind a piece of academic writing is intended to be, whom it serves, and what objectives it expects to achieve (Askehave, 2017). Usually, CPs are not simply realized in the texts that instantiate a genre; rather, they are intertwined with the text space where a genre is mediated or supported, albeit in an intricate manner (Askehave \& Swales, 2001; Swales, 2009). Because as a parent/family genre space academic journals comprise multiple types of text (in other terms, secondary, sub, and microgenres) including but not limited to research articles and book reviews, a global survey of academic journals would provide not only a preliminary account of the interplay between multimodality and academic journal writing prior to elaborating textual analysis but also the broad overview of those genres. For example, how is authorship and/or readership constructed and maintained? This overview makes possible 
more nuanced investigations of the impact of multimodality on academic journal publishing such as multimodal text coherence and navigation (or signposting) and is therefore urgently needed.

In what follows, we will first review the connections between multimodality and English academic writing to provide the backdrop for our research focus on academic journals and the related genres. We will explain why genre is employed as both a theoretical and an analytical lens to approach the current digital emergence. We will then present an analytical framework and use it to delineate the CPs of an open access academic journal, Kairos. Finally, we will discuss the identified features of the CPs to understand their theoretical, methodological, and pedagogical implications for academic journal publishing and writing. We hoped at the start of this probe that our analysis would help answer the following research question: What are the CPs of academic journal writing, and how are they presented?

\section{THE MULTIMODAL TURN}

The interplay between writing, digitization, and multimodality shapes the landscape of academic journal publishing in digital times. Above all, writing in general is known to have evolved rapidly over the last three decades alongside the Internet, social networking, smart computing, and the semantic web. It is shifting from a monomodal regime dominated by written text to become more inclusive of other modes and resources (Kress, 2013). Hypertext and connected multimedia spaces, for instance, have enabled writing to accommodate not only diverse modes, materials, and media but also diverse authorships, readerships, and compositional processes (Jewitt, Bezemer, \& O'Halloran, 2016; Lemke, 2009). This emergence has many implications, such as making writing more accessible or collaborative and rethinking many of the customs or mores involved in writing processes (EdwardsGroves, 2011; McWilliams, Hickey, Hines, Conner, \& Bishop, 2010). Writing overall is becoming increasingly diverse, inclusive, and immersive (e.g. Chang, 2015; Coiro, Knobel, Lankshear, \& Leu, 2014; Gibbins \& Greenhow, 2014).

As a domain of writing, English academic writing is rife with similar changes; it also faces several unique challenges from both institutions and individuals, as well as from the permeating discourses and ideologies over the past few centuries. Three trends are worth special attention in approaching this multimodal turn. Firstly, academic writing for research publishing is usually regarded as a sacred domain (Carroll, 2015); in other words, since academic writing used to be regarded as solely an elitist practice, it was tightly policed in relation to what, how, and who should be involved in the community (c.f. Meredith, 1966). As a result, most traditional research journals would target well-trained academics, discipline experts, or specialists with specialized discourses often enigmatic to non-academic communities. This approach to research publication has become frequently questioned as the knowledge industry expands every day alongside the 
multiplication of disciplinary knowledge, contributors, and consumers. The issue of widening research dissemination, access, and translation is as important as maximizing research production. Secondly, academic writing is conceived of as a process that involves both enculturation and acculturation from a communities of practice perspective (Wenger, 1998). This view seems to resonate with the mainstream process-based academic writing pedagogy, as well as the perception of writing as socialization of individuals through immersive practice. This overemphasis on legitimacy, gatekeeping, and apprenticeship can be problematic at times. It seems to suggest the existence of final destinations and great masters, which is incompatible with, if not contradictory to, the multimodal landscape where even experts are struggling to keep pace with change. Skill differentiation and teamwork on the basis of the division of labor are largely ignored. Thirdly, since English as a lingua franca for research publishing has enlisted many nonnative speakers into the global research arena (Lillis \& Curry, 2016), collaborative writing among speakers of varieties of English (such as using editing services for manuscript proofreading) has become increasingly common (Flowerdew, 2016), even though its mechanisms, processes, and consequences are yet to be scrutinized.

However inclusive these trends may be, many questions remain unanswered. For example, who is entitled to gatekeeping the quality and accountability of academic journals? To what extent would prestigious research journals edited by non-native speakers reshape research publishing conventions? More importantly, how can academics versed in other languages, cultures, and traditions exploit the strengths of this multimodal turn in order to contribute more confidently and effectively to present and future research publishing? This multimodal turn of English academic writing and literacy calls into question many other aspects of research journal publishing. Power struggle, for instance, may shield established researchers from new practices while discouraging junior researchers from taking initiative. A general lack of informed, active practice may increase difficulty in pedagogical modeling and scaffolding, not to mention cultivating immersive, intuitive learning environments. There is also urgency in rallying for institutional and community support for good practice. Most imperatively, the theoretical and methodological frameworks needed to support these types of investigation are yet to take shape.

We consider genre theory a candidate that can be exploited in this type of exploration, partly due to the flexibility genre theory can offer in analyzing various text corpora from literature, media, and social research. Genre analysis can be conveniently applied to capture text patterns, situations, and historicity, which are accessible to sociological or pedagogical interpretations. More importantly, genre theory is open-ended and responsive to other disciplinary developments. For example, the three genre schools labelled by Hyon (1996) have developed through extensive collaborations rather than exclusion since the late 1990s and have converged on many fronts (Hyon, 2017; Swales, 2009). Emphasizing that genre is 
performative and dependent on situations and their participants, some genre theorists, such as Frow (2015), have even challenged various established concepts such as meta-genre, macro-genre, and genre bending, which rely on relatively stable features, categories, or activities for recognition, to implicate power interplay between the expert and the amateur, a tradition that has continued in many studies of genre (Feez \& Zhang, 2014; Swales, 2009).

The arrival of social media spaces also has several significant implications (Gillmor, 2008). Firstly, it continues to create near-infinite media spaces that cater to individual preferences and circumstances. The monomodal and unidirectional transmission of information is no longer the norm. Secondly, it makes the concept of affordance even more prominent in inquiring into the actions that digital, smart technologies can possibly enable to overcome material or physical hurdles. This trend implies that mediation outweighs the identification of genre; in other words, mediation itself becomes a feature of genre or part of generification. This view can be discomforting for some analysts when the nuanced turn-by-turn analyses drawn upon in certain models seem not to be as essential. Whether and how a multimodal text can be perceived as a genre, as well as the way it can be analyzed, may be shaped largely by (a) what the medium is, (b) what the (possible) technological affordances the medium has, and (c) what mediating processes are involved in generating, say, communities, relationships, emotions, or desires (e.g. Liu, 2016).

Spinuzzi's (2003) use of genre ecology also suggests that concepts such as genre sets, genre repertories, and genre systems, albeit illuminating, can be problematic, especially in examining technology-induced genres (such as the Internet genres) - they often imply sequential or hierarchical relations among genres. In his conception of genre ecology, Spinuzzi did not posit clear-cut relations among genres but rather employed Deleuze and Guattari's (1988) assemblage to elucidate the interdependence of people and activities. He argued that decentralization enables distribution of usability, design, and intention across the ecology of genres, while stability helps users make connections between the genres they use. Since genres are dependent on one another, the success of any given genre often depends on its interconnections with other genres, and a genre's constant hybridization and evolution can change the entire activity in genre ecology at a given point in time.

\section{AN ANALYTICAL FRAMEWORK OF COMMUNICATIVE PURPOSES}

While all those recent developments in genre theory are exciting, they add to the difficulty in recognizing genres through their primary markers, namely, communicative purposes. In Swales's (1990) seminal work on genre, communicative purposes were considered a key identifier of a particular genre, its 
functions, and its family (or genre set). Elsewhere, this concept has been termed "social purpose" (Martin, 1992, 2009) or "communicative intention" (Gibson, 1977). CPs as a concept are useful as they allow genre researchers and educators to mark a genre without reliance on elaborate descriptors. Change in the CPs of a genre can significantly alter its configuration and even its classification and/or affiliation, which is often regarded and employed as a primary genre-bending strategy (Hüttner, 2015). One main problem, however, is that the CPs are fluid or can hardly be explicitly captured. While consistent with the generative tendency of digital genres, this attribute makes it extremely difficult to conduct useful genre analysis without a lucid description of the CPs. Various attempts have been made to resolve the problem, which include Swales's collaboration with Askehave (Askehave \& Swales, 2001). Still, as they have demonstrated through their own analysis, this elusive concept is difficult to approach (Askehave, 2017).

To solve this problem, in this article, we mobilize two interrelated concepts, framing and context, to work out a meaningful framework for identifying CPs. Framing is a concept taken from Goffman (1974) to label schemata of interpretation that allow individuals or groups to act on events and occurrences. Two aspects are worth particular attention in understanding framing: the intention of framing and the significance of the frame (Andrews, 2013). The concept of framing and its component, frame, make it possible to introduce context as an analytical tool for CPs. Hypothesized as entities or units, frames are intended to provide temporary, tangible capture of textuality that may trigger varied schematic imaginations, while framing stresses the process, continuity, and complexity in generating frames. Conceptually, it would be incorrect to assume that frames are finite, but in actual analyses, it is only feasible to include a given number of frames. Since it is unrealistic to analyze digital academic journal publishing continuously, it would be useful to approach it in frames and identify the context around them. Because meaning is codependent and situated, context becomes essential in analyzing texts (as entity and process ontological), the relations between and inside texts (as interconnectivity and experience - epistemological), and their positions (as value, belief, and influence axiological). It has been examined over the years by researchers from various disciplines such as ethnography of communication (Hymes, 1967; Saville-Troike, 2003) and writing (Grabe \& Kaplan, 1996). Some researchers, such as Van Dijk (2008), have made substantial commitments to developing comprehensive context analytical models.

The scope and layers of context involved in actual analyses, however, are dynamic, multiple, and even volatile. Such volatility may be caused by the very nature of the size, scale, or importance of texts, which may vary in line with textual and social situations as well as researcher preferences. In this sense, text should not be seen as linear, hierarchical, static, and consistent but rather as seemingly randomly interrelated, interdependent, and progressing. Further, such volatility may also be caused by a temporal evaluation of the participants of text, whether 
the participants are involved in producing or interpreting the text. Context in this sense is subject to participants' mental schemas, which have fixity at a time and keep self-revising in response to social situations as well as to physical presence. Consequently, this is unlikely to provide a comprehensive description of context in analyzing and explaining texts but to produce a series of descriptions of the critical frames being analyzed.

\subsection{A context analysis model}

Rather than adopting a discrete context model, we have decided to develop an insituation model for understanding the CP of academic writing. As is illustrated in Figure 1, the proposed model comprises context source, context marker, and context filter. First, context source, indicative of the source where contextual information is collected, is differentiated as internal and external. This differentiation recognizes that texts are not isolated in making meaning. Context information can be gleaned from a text itself (internal). It can also be gathered from texts around it (external) within or beyond a text ecology. Bauman and Brigg (2003), for instance, regarded texts as essentially cultural objects that are durable, repeatable, classifiable, and linked to other texts by historical, cultural, and generic relationships. Intertextuality is a system of relations that link texts based on shared meanings and formal patterning and shared principles of organization. Fairclough (2003) went further to argue that genre itself is a result of intertextuality. He used the term interdiscursivity to replace genre to emphasize the complexity of textual relations in a single text and a single genre as interrelated textual practice. These textual relations not only have a temporary configuration as governed by the form and functionality of a genre but also have a history and a future. In our context analysis of research journals, the internal source specifies all the relevant texts within a journal itself, whereas external sources refer to other journals, institutions, or networks. We will mainly use hyperlinks embedded in the selected internal text to identify external sources that may provide useful contextual delineation. 


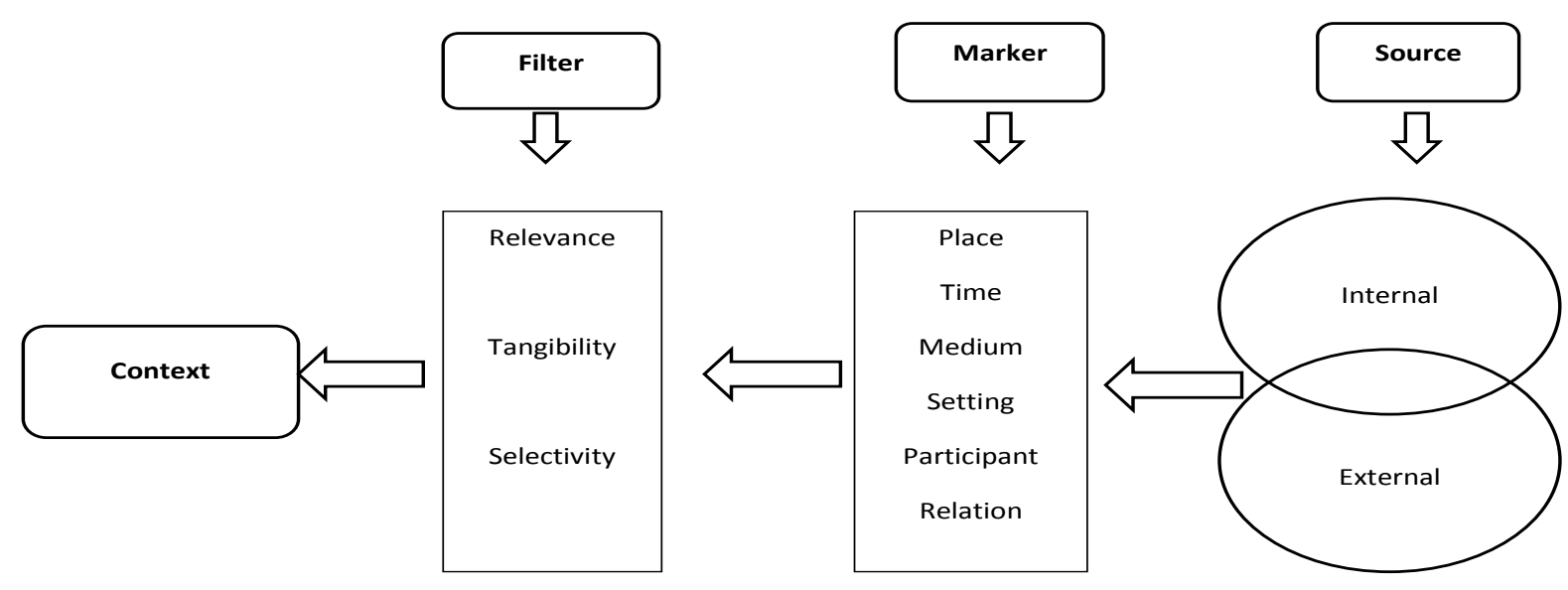

Figure 1. Context analysis

Context markers are key constituents of the context required to recognize a genre. The number and value of context markers are determined by situation and vary accordingly. In other words, what context markers should be included depends on the data, the way the data are generated, and the purpose behind using the data. In our analysis, we include the following context markers in constructing meaningful context: place, time, medium, setting, participant, and relation (c.f. Scollon, Scollon, \& Jones, 2011). Place specifies the physical or virtual location in which a critical frame is identified. Time is not just a physical indicator but also a psychological marker that the participants may express in relation to a situation. Medium describes the way in which a critical frame is conveyed to the audience. Is it via words (written or spoken), pictures, videos, animations, or other? Setting is a descriptor of the physical arrangement of the space in which a critical frame is located. This may otherwise include many other elements, such as layout and typology, depending on the nature of the space. Participants include the parties who are involved in enacting a critical frame. Whether the parties are human or non-human should not be a definitive criterion but be determined by the agency that a party may possess. Certainly, participants are not only individuals but could be collectives or institutions. Sometimes, institutions may play pivotal roles as participants in shaping a critical frame as well as the nature of the context. Finally, a description of relation can provide links among all these factors of context. Such a context vignette can help highlight the relevance of certain context to a critical frame. Even though context is determined subjectively and its border is blurry, context analysts are able to make such analyses economical and manageable by applying context filters as principles to justify a context's situatedness. We find these three context filters pertinent to our analysis: relevance, selectivity, and tangibility. Relevance indicates that a specific context analysis should only include information that is significant or pertinent to the analytical frames. Once a set of context markers is identified as possibly useful, it should be applied consistently 
throughout an analysis. Selectivity requires that factors, variables, or conditioners chosen to delimit a context should be decided based on the objectives of a particular study rather than being exhaustive. This implies that, first, although contextual information is complex and inexhaustible, not all contextual factors should be included in a particular analysis, and second, it is a researcher's decision which contextual factors to account for in his or her studies. Contextual analysis should be minimal and specific rather than general or extensive. Tangibility, the third filter, is similar to selectivity but is singled out in response to the status quo of context analysis.

\subsection{The case}

Over the past two decades a growing number of open access academic journals have contributed to multimodal publishing. In this study, we chose the journal Kairos: A Journal of Rhetoric, Technology, and Pedagogy (available at http://kairos.technorhetoric.net/) as the focus of this single case analysis for a number of reasons. First, Kairos is one of the earliest academic journals committed to remodeling writing and rhetoric in digital times. Second, although it is not the first peer-reviewed online journal in the humanities (or in composition/rhetoric), it is one of the oldest continuous publishing spaces and was the first one to focus on the development of work that draws upon the new media of electronic networks as key elements of digital scholarship. Its continuity provides an opportunity for developing diachronic and synchronic research projects to investigate the evolution of academic writing over time. Third, the journal itself is part of the open-source publishing initiative, which has been gaining momentum and recognition. Fourth, as one of the leading peer-reviewed journals in English studies, Kairos is dedicated to academic quality through its extensive peer-review and editorial production processes, which may help bring forward and support the voices of those too often marginalized in the academy community, pushing the boundaries of academic publishing. Figure 2 is a screenshot of one of the journal's issues (21.1, Fall 2016). An article included in the issue is promoted with a snapshot of its title, author(s), abstract, and featured image. 


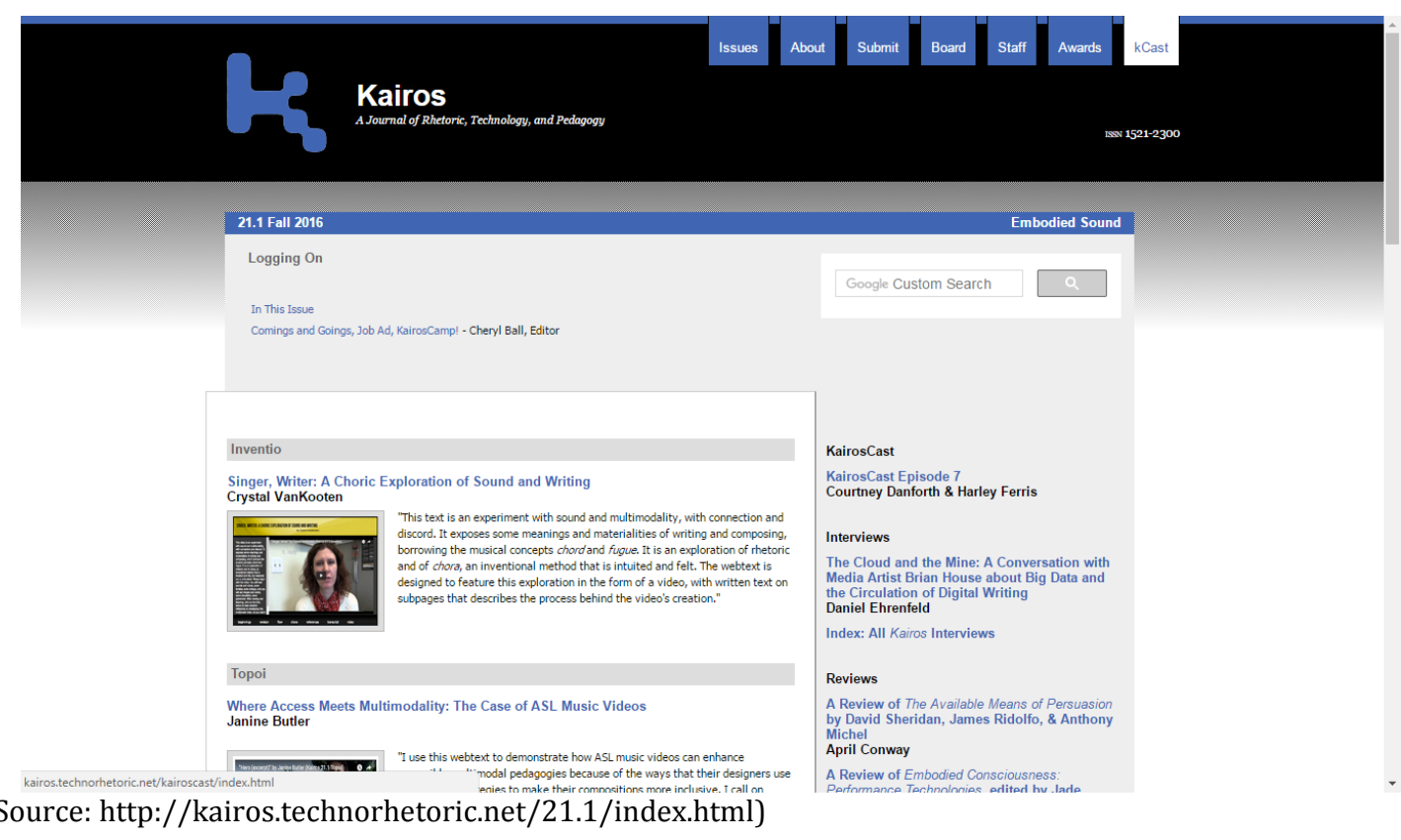

Figure 2. A screenshot of Kairos's Fall 2016 issue

Figure 3 is a screenshot of a research article included in the journal's first 2016 issue. The video, which is a main component of this research product, is foregrounded at the center of middle and above sections of the page whereas the text organization and navigation (beginnings, revision, flow, chora, references, transcript, video) are included at the bottom section as background.

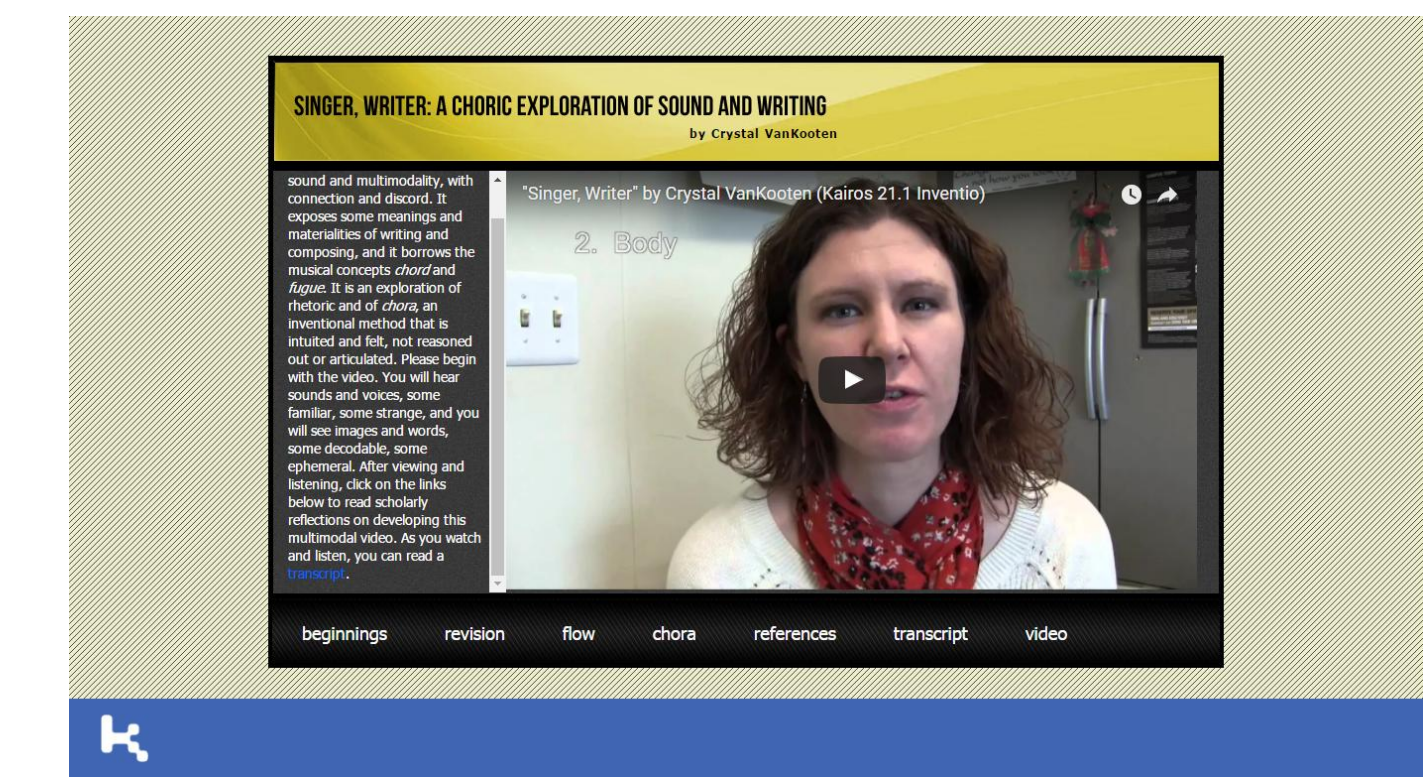

(Source: http://kairos.technorhetoric.net/21.1/inventio/vankooten/index.html)

Figure 3. A screenshot of the first article in Kairos's issue 21.1/2016 
The collected data comprise internal and external sources. Sources identified as created by the journal were labelled Internal, whereas those that hyperlinked to other websites or organizations were labelled External. The communicative purposes identified from the analysis of the data collected from Kairos were archived and coded in NVivo (http://www.qsrinternational.com/nvivo-product), a qualitative analysis software. Altogether, 24 sources were included in the coding, of which, coincidentally, 12 were internal and 12 external. Table 1 provides a summary of these sources. The sources range from introducing the journal (e.g. S01), the journal's intention of publishing works on multimodal rhetoric (e.g. S02), and the journal's unique review process (e.g. S03) to the standards, tools, and applications (e.g. S18, S20, S21) the journal adopts in supporting those functions. This wide range of sources is the first set of indicators of the complexity of the journal's CPs.

\begin{tabular}{|l|l|l|l|}
\hline $\begin{array}{l}\text { SOURCE } \\
\text { NUMBER }\end{array}$ & TITLE & SoURCE & \multicolumn{1}{|c|}{ CoNTENT } \\
\hline S01 & About the Journal & Internal & $\begin{array}{l}\text { Introducing the journal's history, } \\
\text { purposes, and scope of publications }\end{array}$ \\
\hline S02 & Kairos layers of meaning & Internal & $\begin{array}{l}\text { Discussing the meanings and } \\
\text { implications of the journal's name }\end{array}$ \\
\hline S03 & The Kairos editorial review & Internal & $\begin{array}{l}\text { Describing the journal's unique } \\
\text { review process }\end{array}$ \\
\hline S04 & Submitting to Kairos & Internal & $\begin{array}{l}\text { Describing the process of } \\
\text { scholarship submissions to the } \\
\text { journal }\end{array}$ \\
\hline S05 & Style guide & Internal & $\begin{array}{l}\text { Explicating the requirements for } \\
\text { submissions in relation to design, } \\
\text { style, and referencing }\end{array}$ \\
\hline S06 & Call for reviews & Internal & $\begin{array}{l}\text { Recruiting reviewers for multimodal } \\
\text { academic compositions }\end{array}$ \\
\hline S07 & Kairos award & Internal & $\begin{array}{l}\text { Awarding quality multimodal } \\
\text { academic compositions }\end{array}$ \\
\hline S08 & Award winners & Internal & Introducing the winners \\
\hline S09 & Best webtext awards & Internal & $\begin{array}{l}\text { Introducing the award and calling } \\
\text { for nominations }\end{array}$ \\
\hline S10 & The John Lovos award & Internal & $\begin{array}{l}\text { Introducing the award and calling } \\
\text { for nominations }\end{array}$ \\
\hline S11 & Graduate award & Internal & $\begin{array}{l}\text { Introducing the award and calling } \\
\text { for nominations }\end{array}$ \\
\hline S12 & Kairoscast & Internal & Podcasting \\
\hline S13 & Kairosnews & External & Promoting the journal \\
\hline S14 & Kairos PraxisWiki & External & $\begin{array}{l}\text { Providing a practice space } \\
\text { optioviding authors with a range of } \\
\text { online scholarship }\end{array}$ \\
\hline S15 & Topoi & $\begin{array}{l}\text { Connecting to the conferences } \\
\text { organized by the Journal }\end{array}$ \\
\hline S16 & Kairos conference reviews & & Extivering \\
\hline
\end{tabular}




\begin{tabular}{|l|l|l|l|}
\hline S17 & Scholar Names & External & $\begin{array}{l}\text { Audio-archiving the names of the } \\
\text { Journal's contributors }\end{array}$ \\
\hline S18 & $\begin{array}{l}\text { Resources for Evaluating Digital } \\
\text { Scholarship }\end{array}$ & External & $\begin{array}{l}\text { Providing resources for evaluating } \\
\text { digital scholarship }\end{array}$ \\
\hline S19 & Search & External & $\begin{array}{l}\text { Locating information within the } \\
\text { Journal's site }\end{array}$ \\
\hline S20 & $\begin{array}{l}\text { Code of Best Practices in Fair Use } \\
\text { for Scholarly Research in } \\
\text { Communication }\end{array}$ & External & $\begin{array}{l}\text { Interpreting the copyright doctrine } \\
\text { of fair use }\end{array}$ \\
\hline S21 & Creative Commons & External & $\begin{array}{l}\text { Explaining principles and } \\
\text { regulations around knowledge } \\
\text { sharing }\end{array}$ \\
\hline S22 & CSS validation service & External & $\begin{array}{l}\text { Providing technical guidance on } \\
\text { webtext design }\end{array}$ \\
\hline S23 & Markup validation service & External & $\begin{array}{l}\text { Providing technical guidance on } \\
\text { webtext design }\end{array}$ \\
\hline S24 & Wave & External & Providing consistency check \\
\hline
\end{tabular}

(Note: $\mathrm{S}$ stands for Source)

Table 1. Data source

\section{ANALYSIS AND KEY FINDINGS}

The analysis indicates that context markers were employed in coding the identified sources, as is summarized in Table 2 . It should be noted that internal and external sources were coded slightly differently. As an internal source usually comprises one single text (irrespective of length), it is feasible to conduct detailed coding with context markers. A context marker's concentration across the source in this sense may indicate its importance in shaping the CPs. In contrast, an external source often consists of myriads of texts. For example, S21 "Creative Commons" links to its official website, which features regulations and practices related to digital intellectual property recognition and protection. In this regard, it is not manageable to examine all the context markers embedded in those texts unless an umbrella coding system can be created to determine whether a context marker is present in the selected source.

A glimpse into the distribution of context markers nevertheless suggests that in internal sources, participant, setting, and relation have a higher concentration than medium, place, and time, whereas in external sources, relation, medium, and setting are more frequent. That seems to suggest that relation, setting, and participant may play a relatively prominent role in shaping the CPs. The journal might have utilized more resources to establish connections with its prospective users by explicating its position, aspirations, and missions. Caution should be taken in suggesting that place and time are not as relevant in constructing the CPs. That might have been a result of the coding difference, as has been discussed above, and/or a deliberate decision by the journal to redefine its roles on account of 
medium - after all, in online spaces, place and time can be hardly separated from medium itself. In other words, it may be more useful to combine these three context markers in describing the context that shapes the CPs.

\begin{tabular}{|l|l|l|l|l|}
\multirow{2}{*}{\begin{tabular}{l} 
CONTEXT MARKER \\
\cline { 2 - 5 }
\end{tabular}} & \multicolumn{2}{|l|}{ INTERNAL } & \multicolumn{2}{l|}{ EXTERNAL } \\
\cline { 2 - 5 } & Number of source & Total & Number of source & Total \\
\hline Place & 7 & 9 & 1 & 1 \\
\hline Time & 5 & 17 & 2 & 2 \\
\hline Medium & 9 & 19 & 6 & 6 \\
\hline Participant & 11 & 29 & 5 & 6 \\
\hline Setting & 10 & 26 & 6 & 8 \\
\hline Relation & 9 & 25 & 8 & \\
\hline
\end{tabular}

Table 2. Summary of context markers and sources

Table 3 is a summary of the CPs intended in the journal. It presents the identified CPs as well as the texts where the identification was realized. In total, approximately eight CPs have emerged from the analysis of the collected sources, each of them with distinct orientation and importance. It is apparent that the first two CPs (CP01 and CP02) are the most common and visible in nearly all sources except for three external ones (S22, S23, and S24). They are generic to mainstream peer-reviewed research journals: publishing, selecting, and distributing highquality scholarship to increase the impact. It is noteworthy, however, that the journal's approach to these generic CPs is different, or even unique to some extent, as the internal sources S03, S04, and S05 demonstrate. For example, its three-tier review process is not linear or sequential but rather recursive:

[O]ur intention is to publish the webtext if the author or authors complete the revisions requested in consultation with the editors and editorial board. (S03)

This implies that the journal consciously envisages a mission to model, scaffold, and cultivate emerging ways of academic composition.

The two revised generic CPs continue their ramifications in the other six CPs. CP03 manifests the journal's attendance to new writing possibilities afforded by webspaces and technologies and its commitment to this exploration. To realize this, it rejects outright essay-based submissions. In particular, CP04 positions the journal as the space for curating scholarship in new writing since the works submitted to the journal are mostly complete publications prepared in traditional formats. In this regard, the journal is perceived as a virtual museum for exhibiting new types of writing. To a large extent, the other CPs are what differentiate the journal from other traditional academic publishers. Creating such a virtual museum would in turn create an immersive learning environment for the journal's customers to understand, appreciate, learn, and develop new writing genres and 
skills as are promoted in CP05, CP07, and CP08. Naturally, this immersive virtual space creates opportunities for collaboration and further networking between text authors, multimodal webtext production teams, and visitors.

\begin{tabular}{|l|l|l|}
\hline \multirow{2}{*}{ CoMmUnICATIVE PURPoSE } & \multicolumn{2}{l|}{ SOURCE INVOLVED } \\
\cline { 2 - 3 } & Internal & External \\
\hline CP01 Disseminating knowledge & S01, S02, S12 & S13, S14, S15 \\
\hline CP02 Publishing quality scholarship & $\begin{array}{l}\text { S01, S02, S03, S04, S05, } \\
\text { S06 }\end{array}$ & \\
\hline $\begin{array}{l}\text { CP03 Exploring new models of knowledge publishing } \\
\text { and curating }\end{array}$ & S01, S02, S12 & S13, S14, S15 \\
\hline CP04 Curating, exhibiting, and promoting scholarship & $\begin{array}{l}\text { S01, S02, S03, S07, S08, } \\
\text { S09, S10, S11, S07, S08, } \\
\text { S09, S10, S11, S12 }\end{array}$ & $\begin{array}{l}\text { S13, S14, S15, } \\
\text { S16 }\end{array}$ \\
\hline $\begin{array}{l}\text { CP05 Commemorating and acknowledging scholars } \\
\text { and their contributions as public intellectuals }\end{array}$ & $\begin{array}{l}\text { S07, S08, S09, S10, S11 } \\
\text { CP06 Publicizing/promoting/marketing }\end{array}$ & S13, S14, S17 \\
\hline $\begin{array}{l}\text { CP07 Providing professional training/development } \\
\text { through modeling and hands-on practice }\end{array}$ & $\begin{array}{l}\text { S04, S05, S07, S08, S09, } \\
\text { S10, S11 }\end{array}$ & $\begin{array}{l}\text { S13, S17, S14, S15, } \\
\text { S16, S17, S18 }\end{array}$ \\
\hline CP08 Connecting knowledge communities & S03, S05, S06 & $\begin{array}{l}\text { S20, S21, S22, } \\
\text { S23, S24 }\end{array}$ \\
\hline
\end{tabular}

(Note: CP stands for Communicative purpose)

Table 3. Kairos's communicative purposes

Several features of the communicative purposes of the research genres in Kairos are apparent from the analysis of internal and external sources. First, the CPs are neither singular nor linear; rather, they are multiple, varied, and interconnected with one another as independent units or modules. For example, CP03 and CP04 are related to each other closely. Second, the CPs have mostly emerged over the years in response to external development or internal practices. For instance, the journal uses "Creative Commons" (S21) to explain how digital copyright has been consistently observed in its practice. It also adopts or adapts internal sources as model practice to assist its users and authors. "Style guide" (S05), for example, advises authors with an adapted APA reference style based on the webtext "Who's Writing? Aristotelian Ethos and the Author Position in Digital Poetics," which the journal published in the third issue of 2007. More importantly, it seems that for the journal, evaluating and curating high-quality webtexts created elsewhere has become increasingly important in addition to its conventional focus on scholarship publishing and dissemination. Finally, considering the journal's longstanding commitment to scholarship in digital rhetoric and composition, it is not surprising that the editorial team takes pride in the journal's role in exploring and modeling English academic writing. 


\section{DISCUSSION AND CONCLUSIONS}

To start off, we notice that genres germinated in research journals are enacted by multiple semiotic and social resources including modes, media, and modalities, as well as immediate and distant situations. In this respect, design seems a more suitable term than writing for delineating this new trend of academic publishing as well as the kind of practices and activities involved. Several sections of Kairos evidence this feature. "Graduate Award" (S11) encourages student researchers to partake in this multimodal research publishing initiative while having their contributions recognized. "Kairos PraxisWiki" (S14) and "Topoi" (S15) provide spaces that support apprenticeship as well as collaborations between amateurs and established academics. It is evident that compared with other research journals, Kairos has invested a great proportion of resources into the provision of technical guidance and support to its content contributors. This dynamic is an indicator of the ecological interdependence among genre participants instead of a hierarchical relationship. Such an ecological space is capable of generating semiotic and technological resources to engage its participants actively and meaningfully and to ensure the design process is diverse and inclusive, capable of inviting and empowering the participation of previously marginalized or disadvantaged groups.

We also see from the analysis that Kairos as a digitally mediated research transaction space no longer merely fashions a one-way transmission from the research journal to its users. Instead, it is open to negotiations among various stakeholders, as well as with various groups of users, to foster a participatory, open space. In addition to its unmarked mission of publishing peer-reviewed research, Kairos involves users in further evaluating the quality of its research publications through several award selection events (e.g. S07, S09, S11) and other activities (e.g. S12, S13). Kairos imagines an academic journal as a public space openly accessible to immediate and distant communities that elicits or sustains intellectual exchanges, which, wittingly or unwittingly, opens up opportunities to cultivate critical social discourses and actions as the generative power implied in genre assemblage and ecology (Heyd, 2008; Spinuzzi, 2003). For Kairos, associating the journal with many external organizations is more than mapping hypermodal connections (see Lemke, 2009 for more detailed discussion). To some extent, the journal is envisaged as part of the emergent knowledge community committed to exploring new publishing avenues and/or models by subverting the established publishing norms or conventions. Hyperlinking visitors to such external sites as Creative Commons (S21, S22, S23, S24) may manifest this intent to provide institutional and technical support. This also demonstrates to a certain extent how genre complexity increases from the original generic CPs to other types.

Through the lens of assemblage on genre creation (Deleuze \& Guattari, 1988), this also highlights the uncertainty and unpredictability of this shift. On the one hand, the shift aligns closely with the expansion of the web and other digital 
spaces to make content ubiquitous and dispersed. Some researchers (e.g. Siegel, 2012) would argue that a research journal as well as its research outlets should be held responsible for scholarship quality assurance and selection to help save the user's time and attention. On the other hand, the generative power implicated in assemblage transcends the conventional division between simple knowledge generation and knowledge production (Spinuzzi, 2003). In this new paradigm, authors are entrusted with increased responsibility (as well as capacity) in content generation, promotion, and exchange, with teams of various expertise from the journal and/or elsewhere contributing technical, editorial, and other support.

Such an emphasis on agency makes performativity a central piece in this genre work of academic publishing, in the moment and the future. It is therefore not surprising that academic journal-mediated research dissemination is turning into continued, open-ended conversations between authors, journals, editorial boards, reviewers, visitors, and, above all, world wide web communities. Each party performs in consideration of its role, space, and interest. For instance, observing its traditional responsibilities, Kairos also informs its authors of the style of composition, programming, and source selection in preparing their products. Similarly, the authors of the journal do not merely submit their products for review: They are required to have some familiarity with the fundamentals of programming, online editing, and mode interactions. It seems that curation mastery of scholarship has become an emergence rather than an existence, since the journal has used its own model publications to mold the prospective submissions. Scholarship is seen as accretion over time with participation from multiple parties who collaborate and participate recursively and is conceived of as performing public knowledge through repository commitment rather than linear transmission. This taps into the two layers of genre as publicness (Baym \& Boyd, 2012). On one side is Kairos's positioning as an openly accessible public space for its participants; on the other is its attempt to underscore the discourse of knowledge-sharing and research for public good, although it should be noted that some publishing conventions are still rendered necessary due to technical and logistic constraints.

Genre as publicness also helps explain why an academic journal's ability to agglomerate attention is crucial. Attention agglomeration is key to the success of a public media space, be it mass media, we-media, or I-media, where social situations are connected to achieve publicness (Davenport \& Beck, 2013; Sheppard, 2009). This speaks neatly to a recent endeavor of several major publishers to add graphical and video abstracts to research journal articles (e.g. Cell Press available at https://www.cell.com/video/video-abstracts). Having said that, purposeless, chaotic attention-grabbing can become pointless, especially in cultivating academic communities. What matters is how such a public media space manages its contributions and impact while functioning as a node on networking media and academic community spaces and members in a coherent fashion. 
Textual grammar such as coherence still pertains and should be further referenced and examined vigorously.

However elusive the communicative purposes of academic journal writing can be, the analysis presented in this article seems to have substantiated the pertinence of the proposed context analytical framework. To identify the CPs, the first two building blocks are effective in elucidating what types of text (Source) are needed and what kinds of parameters or descriptors (Marker) can be included. Since a great many context analysis models (Van Dijk, 2008) have become too broad to be manageable and transparent, using a context filter as the third building block helps (1) determine where a context analysis should begin and end, and (2) indicate that the selection of context markers and sources is subject to particularized research scenarios rather than predetermined or universal. Although this CP identification model is not intended to eliminate the elusiveness of communicative purposes, it can provide relatively consistent descriptions. It also has the potential to be adapted to process multiple databases or a larger database of academic journals using statistical packages such as SPSS and SAS. Further, the model embodies the very core that connects various aspects of digital genre theorization, as discussed in Section 3, in approaching digital genres and their contingencies - that is, an ecological imagination identical to the algorithm of the Internet, cloud computing, gamification, or appification in which nodes and modules are endowed with greater agency to engender connectivity and attention. However, its application should be undertaken with precautions to avoid biases and overgeneralization. For example, blind cross-checking that involves more than two researchers working independently in data analysis should be implemented to minimize inconsistency and subjectivity in data description and interpretation. There might also be a need to further differentiate the roles of and the relationship among the markers before adopting a statistics package.

In our discussion of the findings, we realize that academic journal publishing in digital times is layered with multiple functions and purposes. The digital academic journal we examined tends to curate various types of research-related issues, events, and activities to invite participation beyond academic communities instead of providing a traditional space of scholarship exchange among career academics. Also, a multimodal design seems to have become a conscious strategy to evade the confines of academic writing. To a certain extent, these findings seem to confirm our observation that CPs of multimodal open-access academic journals have become more complex, elaborate, and fluid than those hosted in print journals and are evolving rapidly in digital times.

To conclude, we are conscious that what we have procured from this study on the communicative purposes of research journal publishing is only a glimpse into this digital transformation. Despite the selected journal's being pioneering and longstanding, there is no doubt that the features that have emerged from the data are preliminary and should be approached with caution. Exploring this new emergence would help demystify the drivers discussed in Section 2 that have 
influenced the evolution of research journals (e.g. their emerging features and configurations). It will also encourage researchers, as well as practitioners beyond academic communities, to explore this evolution's implications for research dissemination and English academic literacy pedagogy and practice, especially in EAL/D (English as an additional language or dialect) contexts (e.g. Li \& Storch, 2017). Several pedagogical issues merit special attention: 1) the complexity that multimodality-saturated research journals are conceived of and developed as expert spaces for scaffolding, participation, or collaboration, for effective, impactful knowledge production and dissemination, 2) changing relationships among student, junior, and senior academics, as well as their interactions with other nonacademic professionals including media creators, and 3) the interplay between explicit academic writing modeling and networked immersive learning where strategies such as peer-to-peer mentoring seem promising. We suggest that further studies be undertaken to invigorate this area of research, either by extending the methodology and the analytical framework to multiple cases or large datasets, or by examining other macro- and micro-generic aspects of research journals including but not limited to organizations, access, subgenres, intertextual/hypermodal relations, and connectivity.

[Paper submitted 10 Aug 2018]

[Revised version received 22 Sep 2018]

[Revised version accepted for publication 7 Oct 2018]

\section{References}

Andrews, R. (2013). A theory of contemporary rhetoric. New York: Routledge.

Askehave, I. (2017). Communicative purpose as genre determinant. HERMES-Journal of Language and Communication in Business, 12(23), 13-23.

Askehave, I., \& Swales, J. (2001). Genre identification and communicative purpose: A problem and a possible solution. Applied Linguistics, 22(2), 195-212.

Bauman, R., \& Briggs, C. L. (2003). Voices of modernity: Language ideologies and the politics of inequality. New York: Cambridge University Press.

Baym, N. K., \& Boyd, D. (2012). Socially mediated publicness: An introduction. Journal of Broadcasting \& Electronic Media, 56(3), 320-329.

Carroll, V. (2015). Science and eccentricity: Collecting, writing and performing science for early nineteenth-century audiences. New York: Routledge.

Chang, H.-J. (2015). Facebook uses, boundary spanning activities, and social capital. Studies in Media and Communication, 3(1), 34-46.

Coiro, J., Knobel, M., Lankshear, C., \& Leu, D. J. (2014). Handbook of research on new literacies. New York: Routledge.

Davenport, T. H., \& Beck, J. C. (2013). The attention economy: Understanding the new currency of business. New York: Harvard Business Press.

Deleuze, G., \& Guattari, F. (1988). A thousand plateaus. New York: Bloomsbury Publishing. 
Edwards-Groves, C. J. (2011). The multimodal writing process: Changing practices in contemporary classrooms. Language and Education, 25(1), 49-64.

Fairclough, N. (2003). Analysing discourse: Textual analysis for social research. London: Routledge.

Feez, S., \& Zhang, Z. (2014). Learning genres. In A. Burns, \& J. C. Richards (Eds.), The Cambridge guide to learning English as a second language (pp. 233-241). New York: Cambridge University Press.

Flowerdew, J. (2016). English for specific academic purposes (ESAP) writing: Making the case. Writing \& Pedagogy, 8(1), 5-32. doi: 10.1558/wap.v8i1.30051

Frow, J. (2015). Genre: The new critical idiom. New York: Taylor \& Francis.

Gibbins, T., \& Greenhow, C. (2014). Students' out-of-school writing practices in an educational Facebook application: The case of hot dish. In R. S. Anderson (Ed.), Handbook of research on digital tools for writing instruction in $K-12$ settings (pp. 154-170). Hershey, PA: IGI Global.

Gibson, J. (1977). The concept of affordances. In R. Shaw, \& J. Bransford (Eds.), Perceiving, acting, and knowing: Towards an ecological psychology (pp. 67-82). Hoboken, NJ: John Wiley \& Sons, Inc.

Gillmor, D. (2008). We the media: Grassroots journalism by the people, for the people. Sebastopol: O'Reilly Media.

Goffman, E. (1974). Frame analysis: An essay on the organization of experience. New York: Harvard University Press.

Grabe, W., \& Kaplan, R. B. (1996). Theory and practice of writing. Malaysia, Clp: Adison Wesley Longman Limited.

Heyd, T. (2008). Email hoaxes: Form, function, genre ecology. New York: John Benjamins Publishing.

Hüttner, J. (2015). Communicative purpose in student genres: Evidence from authors and texts. Fremdsprachen Lehren und Lernen, 44(1), 29-43.

Hymes, D. (1967). Models of the interaction of language and social setting. Journal of Social Issues, 23(2), 8-28.

Hyon, S. (1996). Genre in three traditions: Implications for ESL. TESOL Quarterly, 30(4), 693-722.

Hyon, S. (2017). Introducing genre and English for specific purposes. New York: Routledge.

Jewitt, C., Bezemer, J., \& O'Halloran, K. (2016). Introducing multimodality. New York: Routledge.

Kress, G. (2013). Multimodality: A social semiotic approach to contemporary communication. New York: Routledge.

Lemke, J. (2009). Multimodality, identity, and time. In C. Jewitt (Ed.), The Routledge handbook of multimodal analysis (pp. 140-150). Abingdon: Routledge.

Li, M., \& Storch, N. (2017). Second language writing in the age of CMC: Affordances, multimodality, and collaboration. Journal of Second Language Writing, 35, 1-5. https://doi.org/10.1016/j.jslw.2017.05.012

Lillis, T., \& Curry, M. J. (2016). Academic writing for publication in a multilingual world. In R. M. Manchón, \& P. K. Matsuda (Eds.), Handbook of second and foreign language writing (pp. 201-222). Boston: De Gruyter.

Liu, J. (2016). Beyond genre? Schematically framing Lady Gaga in the dynamics of pop culture production. Journal for Communication \& Culture, 5(1), 18-37. 
Martin, J. R. (1992). English text: System and structure. New York: John Benjamins Publishing.

Martin, J. R. (2009). Genre and language learning: A social semiotic perspective. Linguistics and Education, 20(1), 10-21.

McWilliams, J., Hickey, D. T., Hines, M. B., Conner, J. M., \& Bishop, S. C. (2010). Using collaborative writing tools for literary analysis: Twitter, fan fiction and the crucible in the secondary English classroom. Journal of Media Literacy Education, 2(3), 238245.

Meredith, P. (1966). Instruments of communication: An essay on scientific writing. New York: Pergamon Press.

Saville-Troike, M. (2003). The ethnography of communication: An introduction (3rd ed.). Malden, MA: Blackwell.

Scollon, R., Scollon, S. W., \& Jones, R. H. (2011). Intercultural communication: A discourse approach. Chichester, West Sussex: John Wiley \& Sons, Inc.

Sheppard, J. (2009). The rhetorical work of multimedia production practices: It's more than just technical skill. Computers and Composition, 26(2), 122-131. doi:10.1016/j.compcom.2009.02.004

Siegel, M. (2012). New times for multimodality? Confronting the accountability culture. Journal of Adolescent \& Adult Literacy, 55(8), 671-681.

Spinuzzi, C. (2003). Tracing genres through organizations: A sociocultural approach to information design. Cambridge, MA: MIT Press.

Swales, J. (1990). Genre analysis: English in academic and research settings. Cambridge: Cambridge University Press.

Swales, J. (2009). Worlds of genre: Metaphors of genre. In C. Bazerman, A. Bonini, \& D. Figueiredo (Eds.), Genre in a changing world (pp. 3-16). Fort Collins, CO \& West Lafayette, IN: The WAC Clearinghouse \& Parlor Press.

Van Dijk, T. A. (2008). Discourse and context: A sociocognitive approach. Cambridge: Cambridge University Press.

Wenger, E. (1998). Communities of practice. London: Cambridge University Press.

JIANXIN LIU lectures in ESL and literacy education at Charles Sturt University. He is interested in applied linguistics, new literacies, social media studies, and critical cultural inquiry and has produced many publications in these areas.

JEBUNESSA JEBA is a PhD student in the Faculty of Arts and Education of Charles Sturt University. Her doctoral project focuses on investigating the evolution of academic writing in digital times. 